\title{
ADMINISTRASI PENYULUHAN PERTANIAN PADA KELOMPOK TANI DI KECAMATAN TABUKAN UTARA KABUPATEN KEPULAUAN SANGIHE
}

\author{
Virginia Mauren Rambitan \\ Benu Olfie L. S. \\ Ellen G. Tangkere
}

\begin{abstract}
This study aims to determine the condition of the agricultural extension services administrative completeness of of farmer groups in the Sub-district of North Tabukan, Sangihe Islands District. The study lasted for 3 (three) months starting from January 1 to April 1 in 2016. Sampling method on two farmer groups in Tabukan North Sub-district done by purposive sampling. The first farmers group office located in Talolang Village near to the office of BP3K and the second farmer group located in Lenganeng Village far from BP3K. The asumption of this research is the farmer group near BP3K office more easily and quickly to obtain information from the agriculture extension service officer, than the farmer groups away from BP3K office. Data collection method in this study is survey method. The data used are primary data obtained from interviews, based on a list of questions, with the core committee Farmers Group (Chairman, Secretary, and Treasurer). The analysis method used in this research is qualitative descriptive analysis using criteria 1 (No Good), 2 (less good), 3 (Good). Data generated to determine the completeness of the administrative and financial administration at the farmer groups. The results of the study on two groups of farmers which Farmers Group Sengkanaung in Talolang Village and farmer groups Lestari 2 in Lenganeng Village shows that administrative of activities and financial administration of farmer groups Lestari 2 Lenganeng all fittings administration books categorized good (3) because of the activity, together with the board members, and members of the extension of farmer groups in conducting all activities. Administrative and financial administration in farmer groups Sengkanaung in Talolang Village not go well and not considered either (1) because there is no cooperation among the members of farmer groups, as well as between members of the farmer group with the agricultural extension services officer, as well as lack of knowledge and lack of guidance and advocacy for farmers' groups about the completeness of the administrative and financial administration. This conclude that the distance of location between farmer group office and the office of BP3K tend not affect the completeness of the administrative and financial work.
\end{abstract}

Key words : the administrative of agricultural extension services, farmer groups, the Sub-district of North Tabukan, Sangihe Islands District

\section{ABSTRAK}

Penelitian ini bertujuan untuk mengetahui kondisi kelengkapan administrasi penyuluhan pertanian pada kelompok tani di Kecamatan Tabukan Utara Kabupaten Kepulauan Sangihe. Penelitian ini berlangsung selama 3 (tiga) bulan yaitu mulai dari Bulan 1 Januari - 1 April 2016. Metode pengambilan sampel pada kelompok tani yang ada di Kecamatan Tabukan Utara Kabupaten Sangihe dilakukan dengan cara sengaja (Purposive Sampling), pada dua kelompok tani yang lokasi dekat dengan kantor BP3K yaitu Desa Talolang dan kelompok tani yang lokasi jauh dari BP3K yaitu Desa Lenganeng, karena kelompok tani yang dekat dengan BP3K lebih mudah dan cepat mendapatkan informasi dari penyuluh, dari pada kelompok tani yang jauh dari BP3K. Metode Pengumpulan data dalam penelitian ini menggunakan metode survey. Data yang digunakan adalah data primer yang diperoleh dari wawancara langsung dengan pengurus inti Kelompok Tani (Ketua, Sekertaris, Bendahara) berdasarkan daftar pertanyaan. Metode Analisis yang digunakan dalam penelitian ini adalah metode analisis deskriptif kualitatif dengan menggunakan kriteria 1 (Tidak Baik), 2 (Kurang baik), 3 (Baik). Data yang dihasilkan untuk mengetahui kelengkapan administrasi kegiatan dan administrasi keuangan pada kelompok tani. 
Hasil penelitian pada dua kelompok tani yaitu Kelompok Tani Sengkanaung, Desa Talolang dan kelompok tani Lestari 2 Desa Lenganeng, yang mewakili seluruh kelompok tani yang ada di Kecamatan Tabukan Utara Kabupaten Kepulauan Sangihe menunjukkan bahwa administrasi kegiatan dan administrasi keuangan kelompok tani Lestari 2 Desa Lenganeng semua kelengkapan buku administrasi di kategorikan baik (3) karena keaktifan, kebersamaan pengurus dengan anggota, dan anggota dengan penyuluh kelompok tani dalam melakukan semua kegiatan. Administrasi kegiatan dan administrasi keuangan yang ada di kelompok tani Sengkanaung Talolang tidak berjalan dengan baik dan dikategorikan tidak baik (1) karena tidak ada kerjasama antar anggota kelompok tani, begitu juga antara anggota dengan penyuluh, serta pengetahuan yang kurang, dan kurangnya penyuluhan bagi kelompok tani tentang kelengkapan administrasi kegiatan dan administrasi keuangan. Kelompok tani yang dekat dengan kantor BP3K dan kelompok tani yang jauh dari BP3K cenderung tidak mempengaruhi kelengkapan administrasi kegiatan dan keuangan yang ada di Kecamatan Tabukan Utara Kabupaten Kepulauan Sangihe karena dari hasil penelitian ini kelompok tani yang jauh lebih aktif dalam kegiatan kelompok dari pada kelompok tani yang dekat dengan kantor BP3K.

Kata kunci: administrasi kegiatan dan keuangan, kelompok tani, Kecamatan Tabukan Utara, Kabupaten Kepulauan Sangihe

\section{PENDAHULUAN}

\section{Latar belakang}

Pertanian merupakan kegiatan pemanfaatan sumber daya hayati yang dilakukan manusia untuk menghasilkan bahan pangan, bahan baku industri, atau sumber energi, serta untuk mengelola lingkungan hidupnya. Pertanian yang luas mencakup semua kegiatan yang melibatkan pemanfaatan makhluk hidup (termasuk tanaman, hewan, dan mikrobia) untuk kepentingan manusia. Dalam arti sempit, diartikan sebagai kegiatan pembudidayaan tanaman. Bagian terbesar penduduk dunia bermata pencaharian dalam bidang-bidang di lingkup pertanian (Nopriadi, 2013).

Kelompok tani mempunyai peran yang sangat penting dalam berbagai kegiatan pertanian baik yang berhubungan dengan usaha tani maupun kegiatan sosial ekonomi. Peningkatan pembinaan kelompok tani diarahkan pada penerapan sistem agribisnis, peningkatan peranan, peran serta petani dan anggota masyarakat pedesaan lainnya dengan menumbuh kembangkan kerja sama antar petani dan pihak lain yang terkait untuk mengembangkan usaha taninya. Kelompok tani yang berkembang bergabung dengan kelompok tani lain dalam satu wilayah tertentu yaitu desa untuk mengembangkan fungsinya sehingga mempunyai kemandirian yang kuat, lebih mudah menjalin kemitraan dan dapat mengembangkan fungsi kelompok tani. Adanya tanggung jawab dari para ketua kelompok dalam administrasi kelompok tani sangat membantu anggota kelompok agar tercipta hubungan kerja sama yang baik, dan menjadi kelompok tani yang unggul dalam setiap kegiatan.

Petani sering di hadapkan dengan sosialisasi dan penyuluh pertanian, didalamnya penyuluh memenuhi administrasi. Administrasi yang dimaksud adalah administrasi penyuluhan agar kegiatan sosialisasi berjalan dengan lancar atau terstruktur. Kelembagaan penyuluhan pertanian merupakan salah satu wadah organisasi yang terdapat dalam Dinas Pertanian. Kelembagaan pertanian menyesuaikan dengan perubahanperubahan yang ada. Organisasi digunakan sebagai tempat atau wadah dimana orangorang berkumpul, bekerjasama secara rasional dan sistematis, terencana, terorganisasi, terpimpin dan terkendali, dalam memanfaatkan sumber daya (uang, material, mesin, metode, lingkungan), sarana-parasarana, data, dan lain sebagainya yang digunakan secara efisien dan efektif untuk mencapai tujuan organisasi (Ode, 2014).

Administrasi sangat penting dalam suatu organisasi. Keberhasilan suatu organisasi dapat diukur juga dari administrasi. Dalam penyelenggaraan kerja yang dilakukan oleh orang-orang secara bersama-sama (kerjasama) untuk mencapai suatu tujuan yang ditetapkan dan juga admnistrasi yang menjalankan suatu kegiatan kelompok tani, 
dimana Administrasi ini berupa buku daftar anggota, daftar tamu, keuangan, hadir rapat, dan lain-lain administrasi sangat diperlukan. Administrasi pertanian sangat penting bagi masyarakat kususnya kelompok tani, dengan adanya sumberdaya manusia merupakan salah satu faktor kunci dalam reformasi ekonomi, yaitu menciptakan sumberdaya manusia yang berkualitas dan memiliki keterampilan serta berdaya saing tinggi dalam menghadapi persaingan global yang selama ini terabaikan.

Kabupaten Kepulauan Sangihe sebagian besar merupakan masyarakat petani dan masing-masing kecamatan memiliki kelompok tani.Salah satu kecamatan yang terdapat kelompok tani yaitu Kecamatan Tabukan Utara (TABUT). Menjadi hal yang sangat menarik untuk diteliti adalah bagaimana admnistrasi kelompok tani di Kecamatan Tabukan Utara yang diukur dari atau diwakili oleh dua kelompok tani yang letaknya jauh dari BP3K dan dekat dengan BP3K.

\section{Perumusan Masalah}

Berdasarkan latar belakang yang menjadi masalah dalam penelitian ini yaitu bagaimana administrasi penyuluhan pertanian pada kelompok tani?

\section{Tujuan Penelitian}

Berdasarkan uraian diatas maka Penelitian ini bertujuan untuk mengetahui administrasi penyuluhan pertanian pada kelompok tani di Kecamatan Tabukan Utara Kabupaten Kepulauan Sangihe.

\section{Manfaat Penelitian}

Penelitian ini diharapkan dapat bermanfaat untuk lebih mengembangkan administrasi penyuluhan pertanian pada kelompok-kelompok tani, dan terlebih kusus kepada kelompok tani yang ada di Kecamatan Tabukan Utara Kabupaten kepulauan Sangihe.

\section{METODOLOGI PENELITIAN}

\section{Waktu dan Tempat Penelitian}

Penelitian ini berlangsung selama (tiga) bulan yaitu mulai dari Bulan 1 Januari -
1 April 2016. Tempat penelitian dilakukan di Kecamatan Tabukan Utara Kabupaten Kepulauan Sangihe.

\section{Metode Pengambilan Sampel}

Metode pengambilan sampel pada kelompok tani yang ada di Kecamatan Tabukan Utara Kabupaten Sangihe dilakukan dengan cara sengaja (Purposive Sampling), pada 2 (dua) kelompok tani yang lokasi dekat dengan kantor BP3K (Desa Talolang) dan kelompok tani yang lokasi jauh dari BP3K (Desa Lenganeng) karena pada saat pemeriksaan dari lembaga yang terkait dengan kelompok tani yang menjadi contoh, kelompok tani dekat dengan kantor BP3K karena adanya sosialisasi, selalu mendapatkan informasi dari penyuluh, dan lebih diperhatikan oleh Balai Penyuluhan Pertanian Perikanan dan Kelautan Desa Talolang Kecamatan Tabukan Utara Kabupaten Kepulauan Sangihe dari pada kelompok tani yang jauh dari BP3K.

\section{Metode Pengumpulan Data}

Metode yang digunakan dalam penelitian ini yaitu metode survey. Data yang digunakan data primer yang diperoleh dari wawancara langsung dengan anggota kelompok Tani (Ketua, Sekertaris, Bendahara) berdasarkan daftar pertanyaan yang disiapkan.

\section{Konsep dan Pengukuran Variabel}

1. Karakteristik kelompok tani (Ketua, Sekertaris, Bendahara)

2. Karakteristik kelompok tani

a. Nama kelompok tani

b. Tahun berdiri kelompok tani

c. Jumlah anggota kelompok tani

d. Admnistrasi kelompok tani di lihat dari 2 bagian pokok administrasi yaitu administrasi kegiatan (Buku induk anggota, Buku kegiatan kelompok, Buku tamu, Buku notulen rapat, Buku agenda surat msuk dan surat keluar, Buku ekspedisi, Buku Pengurus, Buku daftar hadir, Buku produktifitas dan hasil produksi, Buku luas lahan garapan. Dan administrasi keuangan (Buku Kas, Buku Iuran Anggota, Buku tabungan anggota, Buku inventaris, Buku penjualan, Buku 
pembelian, Buku kepimilikan sarana / prasarana anggota. yang dapat di ukur lewat:

1. Baik (3) = di ukur dengan melihatnya kelengkapan administrasi dalam kelompok tani (administrasi kegiatan dan administrasi keuangan (buku di isi lengkap)

2. Kurang Baik (2) = di lihat dari kelengkapan administrasi (administrasi kegiatan dan admnistrasi keuangan (buku tidak di isi lengkap)

3. Tidak baik (1) = di ukur dengan melihatnya kelengkapan adminstrasi (administrasi kegiatan dan administrasi keuangan ( buku tidak ada)

\section{Analisis Data}

Metode Analisis yang digunakan dalam penelitian ini adalah metode analisis deskriptif kualitatif dengan mendeskripsikan dari tabel penelitian, dengan kriteria 1 (tidak baik), 2 (kurang baik), 3 (baik) Ridwan (2012). Dengan data yang dihasilkan, maka akan diketahui kelengkapan dalam administrasi kegiatan dan administrasi keuangan pada kelompok tani yang merupakan konsep variabel.

\section{HASIL DAN PEMBAHASAN}

\section{Deskripsi Lokasi Penelitian Geografis}

Balai Penyuluhan Pertanian Perikanan dan Kehutanan (BP3K) Talolang adalah bagian dari Kecamatan Tabukan Utara yang mempunyai empat belas (14) desa binaan. Batas wilayah administrasi Kecamatan Tabukan Utara :
- Sebelah Utara dengan Kecamatan Nusa Tabukan

- Sebelah Timur dengan Kecamatan Tabukan Tengah

- Sebelah Selatan dengan Kecamatan Tahuna Timur dan Tahuna

- Sebelah Barat dengan Kecamatan Kendahe

Iklim

Keadaan iklim dipengaruhi oleh angin Muson yang pada bulan - bulan tertentu musim penghujan, pada bulan September sampai dengan Nopember musim pancaroba serta musim kemarau terjadi pada Bulan Juli sampai dengan September.

\section{Topografi}

Topografi Kecamatan Tabukan Utara secara umum datar serta bergelombang dan bergunung dimana ada beberapa Desa yang mempunyai potensi untuk lahan pertanian, khususnya usahatani tanaman pangan dan hortikultura.

\section{Karakteristik Kelompok Tani}

Kelompok tani pada dasarnya merupakan kelembagaan petani dipedesaan yang saling mengenal akrab dan saling percaya antara anggota kelompok tani, mempunyai pandangan dan kepentingan serta tujuan yang sama dalam berusaha tani. Kerja sama antara pengurus dengan anggota, anggota dengan penyuluh sangat berpengaruh bagi perkembangan usahatani dalam kelompok. Tabel 1 menunjukkan karakteristik kelompok tani.

Tabel 1. Karakteristik Kelompok Tani

\begin{tabular}{llccc}
\hline No & Karakteristik Kelompok & \multicolumn{2}{c}{ Kelompok tani } & Total \\
\cline { 3 - 5 } & \multicolumn{1}{c}{ Tani } & Lestari 2 & Sengkanaung & \\
\hline 1 & Alamat & Lenganeng & Talolang & - \\
2 & Tahun Terbentuk & 2009 & 2009 & - \\
\hline 3 & Jumlah Anggota & $\mathbf{1 8}$ & $\mathbf{1 5}$ & $\mathbf{3 3}$ \\
\hline & Sumber : Diolah dari data primer 2016 & &
\end{tabular}

\section{Karakteristik Responden}

\section{Umur Responden}

Tingkat umur mempengaruhi kemampuan seseorang dalam melakukan aktifitas maupun konsep berpikir khususnya tiap anggota kelompok tani. Anggota kelompok tani yang memiliki umur muda tentunya tentunya memiliki kondisi fisik yang lebih kuat, keinginan untuk mencoba hal baru, serta memiliki daya berpikir yang 
kreatif. Selain itu anggota kelompok tani yang berumur tua cenderung untuk lebih menjaga kesehatannya. Dari data primer yang di peroleh, usia responden kelompok tani antara 33-72 tahun. Komposisi umur responden dalam penelitian ini disajikan pada Tabel 2.

Tabel 2 menunjukkan bahwa jumlah responden dari 2 Kelompok Tani Lestari 2 "Desa Lenganeng dan Kelompok Tani Sengkanaung Desa Talolang. Masingmasing berada pada interval umur 41-50 tahun yaitu orang $(33,33 \%)$. Selanjutnya berada pada interval umur 30-40 tahun, 5160 tahun, 61-70 tahun, >70 masing-masing $(33,33 \%) 1$ responden.

\section{Jabatan Responden}

Jenis Jabatan sangat penting dalam mengelola atau menjalankan suatu organisasi, karena jabatan yang dimaksud disini adalah jabatan ketua, sekertaris dan bendahara dengan adanya ketua, sekertaris, bendahara organisasi akan berjalan dengan baik namun demikian jabatan ketua, sekertaris, bendahara harus tercipta kerjasama dengan anggota kelompok tani sehingga semua kegiatan dapat berjalan dengan baik. Tabel 3 menunjukkan jumlah responden menurut jenis jabatan.Tabel 3 menunjukkan bahwa dalam penelitian ini terdapat 3 kategori jenis jabatan dari responden, yaitu ketua, sekertaris, bendahara, masing-masing sebanyak 2 responden $(33,33 \%)$.

\section{Pendidikan Responden}

Tingkah laku individu atau seseorang sangat dipengaruhi oleh pendidikan yang telah dicapai. Begitu juga pada anggota kelompok tani, tingkat pendidikan dan pengalaman sangat mempengaruhi cara berpikir. Pada Tabel 4 menunjukkan tingkat pendidikan pada kelompok tani Letari 2 Desa Lenganeng, dengan responden terbanyak yaitu SLTA sebanyak 3 responden $(100 \%)$, karena kelompok tani Lestari 2 merupakan

kelompok Wanita tani sehingga kelompok sangat aktif dalam setiap kegiatan dan juga pengetahuan yang dimiliki setiap anggota kelompok sangat berpengaruh bagi kemajuan kelompok tani. Sedangkan Kelompok tani Sengkanaung Desa Talolang yang dekat dengan kantor BP3K, tingkat SD sebanyak 2 responden $(66,76 \%)$, dan tingkat SMP sebanyak 1 responden $(16,67 \%)$ karena pengetahuan, kurangnya kerjasama sehingga kegiatan kelompok tani Sengkanaung tidak berjalan dengan baik.

\section{Pengalaman Berusahatani}

Tingkah laku individu pada seseorang sangat dipengaruhi oleh lamanya berusahatani, karena mempengaruhi cara berpikir seseorang lebih lama kita bekerja lebih menambah wawasan seseorang anggota dalam setiap kegiatan dan lebih mengetahui apa yang belum diketahui oleh anggota yang baru. Tabel 5 menunjukkan jumlah responden menurut pengalaman bekerja.

Tabel 7 menunjukkan tingkat lamanya pengalaman berusahatani setiap responden menjadi anggota kelompok tani terbanyak yaitu 8 tahun sebanyak 3 responden (50,00\%), sedangkan 7 tahun 2

Tabel 2. Jumlah Responden Menurut Tingkat Umur

\begin{tabular}{cccccc}
\hline No & Umur (Tahun) & \multicolumn{2}{c}{ Jumlah Responden } & \multicolumn{2}{c}{ Presentase (\%) } \\
\cline { 3 - 6 } & & Lestari 2 & Sengkanaung & Lestari 2 & Sengkanaung \\
\hline $\mathbf{1}$ & $\mathbf{3 0}-\mathbf{4 0}$ & $\mathbf{1}$ & - & - & $\mathbf{3 3 , 3}$ \\
$\mathbf{2}$ & $\mathbf{4 1 - 5 0}$ & 1 & 1 & $\mathbf{3 3 , 3 3}$ & $\mathbf{3 3 , 3 3}$ \\
$\mathbf{3}$ & $\mathbf{5 1 - 6 0}$ & 1 & - & 33,33 & - \\
$\mathbf{4}$ & $\mathbf{6 1 - 7 0}$ & - & 1 & - & $\mathbf{3 3 , 3 3}$ \\
$\mathbf{5}$ & $>\mathbf{7 0}$ & - & 1 & $\mathbf{3 3 , 3 3}$ & \\
\hline & & $\mathbf{3}$ & $\mathbf{3}$ & $\mathbf{1 0 0}$ & \\
\hline
\end{tabular}

Sumber : Diolah dari data primer 2016 
Tabel 3. Jumlah Responden Menurut jenis Jabatan

\begin{tabular}{clcc}
\hline No & $\begin{array}{c}\text { Jenis } \\
\text { Jabatan }\end{array}$ & $\begin{array}{c}\text { Jumlah } \\
\text { Respon- } \\
\text { den }\end{array}$ & $\begin{array}{c}\text { Persen-tase } \\
(\mathbf{\%})\end{array}$ \\
\hline 1 & Ketua & 2 & 33,33 \\
2 & Sekertaris & 2 & 33,33 \\
3 & Bendahara & 2 & 33,33 \\
\hline Jum & & $\mathbf{6}$ & $\mathbf{1 0 0}$ \\
lah & & & \\
\hline
\end{tabular}

Sumber : Diolah dari data primer 2016

\section{Admnistrasi Kegiatan Kelompok Tani Lestari Desa Lenganeng Kecamatan Tabukan Utara}

Administrasi kegiatan merupakan penyusunan dan pencatatan data serta informasi, dengan tujuan untuk menyediakan keterangan. Kegiatan kerja sama yang dilakukan anggota kelompok tani berdasarkan pembagian kerja baik itu sebagai ketua, sekertaris, bendahara. Administrasi kegiatan sangat penting bagi setiap organisasi kelompok tani untuk menunjang kemajuan kelompok tani dimana semua kekurangan dan kelebihan dalam kelompok bisa kita ketahui melalui pembukuan administrasi kegiatan. Administrasi kegiatan kelompok tani Lestari 2 di Desa Lenganeng dapat dilihat pada Tabel 6.

Kelompok Tani Lestari 2" Desa Lenganeng adalah salah satu kelompok di wilayah kerja Balai Penyuluhan Pertanian Perikanan dan Kehutanan (BP3K) di Kecamatan Tabukan Utara, dan jarak tempuh dari BP3K menuju ke lokasi kelompok tani \pm 25 menit. Kelompok Lestari merupakan salah satu kelompok wanita tani yang masih aktif dengan jumlah anggota kelompok tani seluruhnya berjumlah 18 orang mulai Tahun 2009 (Berdiri) sampai dengan sekarang.

Tanaman hortikultara adalah tanaman yang paling dominan di kelompok wanita tani Desa Lenganeng yaitu berupa tanaman ubi jalar dan caisim. Kerja sama antara pengurus dan anggota sangat penting bagi suatu organisasi, sehingga administrasi kegiatan kelompok tani ini bisa berjalan dengan sangat baik meskipun ada beberapa buku yang belum dimengerti oleh semua anggota kelompok.

Ada beberapa buku administrasi kegiatan yang ada di kelompok yang kriteria responden $(33,33 \%)$, dan 3 tahun 1 responden $(16,67 \%)$.

dikatakan baik (3) dan kriteria tidak baik (1), yaitu sebagai berikut :

1) Buku Induk anggota, buku induk anggota adalah kegiatan yang dilakukan dalam suatu organisasi untuk mencatat semua nama-nama anggota yang ada dalam kelompok tani. Hasil penelitian ini menujukan bahwa buku induk anggota dengan kriteria baik (3). Buku ada dan diisi dengan lengkap oleh pengurus kelompok, dan juga tidak ada kendala dalam pembuatan buku induk anggota kelompok.

2) Buku kegiatan kelompok, buku kegiatan kelompok yaitu semua kegiatan yang dilakukan oleh kelompok tani baik dalam ruangan maupun luar ruangan dan dicatat dalam pembukuan. Hasil dari penelitian ini menunjukkan bahwa setiap kegiatan kelompok tani Lestari 2 baik penanaman, rapat dan lain-lain yang berhubungan dengan kelompok tani selalu dicatat oleh sekertaris maupun anggota, sehingga kriteria baik (3) buku ada dan diisi lengkap.

3) Buku tamu, buku tamu juga menunjang kemajuan kelompok tani Lestari 2, buku tamu memungkinkan kelompok tani untuk mengetahui lebih lanjut tentang pengunjung yang datang. Data yang diperoleh dari kelompok tani Lestari baik (3) karena setiap tamu yang berkunjung buku sudah disediakan dan siap untuk dicatat oleh pengunjung yang datang.

4) Buku notulen rapat, buku notulen sangat berpengaruh bagi suatu organisasi kelompok, buku notulen catat mecatat ketika mengikuti pertemuan memungkinkan kelompok mengetahui hal-hal yang penting untuk mengembangkan kelompok tani. Buku notulen rapat pada kelompok tani Lestari 2 Desa Lenganeng dikatakan sangat baik dan masuk pada kriteria (3), karena buku ada dan diisi lengkap oleh sekertaris maupun anggota yang membantu. 
5) Buku agenda surat masuk dan surat keluar untuk mencatat surat yang diterima oleh kelompok dan mecatat surat yang dikirim untuk siapa beserta nomor surat. Buku agenda surat masuk dan surat keluar tidak pernah diterima oleh kelompok tani, karena setiap ada informasi pemberitahuan hanya disampaikan penyuluh kepada ketua, sekertaris, bendahara dan juga anggota lewat media hanphone. Dan kriteria buku agenda surat masuk dan surat keluar menunjukkan tidak baik (1) buku tidak ada.

6) Buku ekspedisi merupakan buku pengantar surat untuk mencatat pengiriman surat kepada pihak lain. Kriteria buku ekspedisi dikatakan tidak baik (1) buku tidak ada, karena dari awal berdiri kelompok tani tidak pernah membuat surat untuk menjadi pemberitahuan.

7) Buku pengurus, sangat penting bagi setiap anggota kelompok tani Lestari 2. Setiap anggota kelompok tani yang ada memilki buku masing-masing untuk mencatat hal-hal yang penting yang untuk bisa menunjang kemajuan kelompok tani, agar tercipta kerjasama antar anggota dan satu pemikiran dalam satu kelompok. Sehingga penelitian ini menunjukkan kriteria yang sangat baik dengan bobot (3) buku ada dan diisi lengkap oleh pengurus maupun anggota yg memiliki buku pengurus pribadi.

8) Buku daftar hadir, sangat berpengaruh bagi kelompok setiap kegiatan pertemuan baik itu rapat sesama anggota kelompok, anggota dengan penyuluh pembantu, maupun pertemuan di kebun saat melakukan penanaman. Sangat aktif dalam menjalankan buku daftar hadir anggota, untuk mengetahui keaktifan anggota kelompok di setiap kegiatan, dengan hasil penelitian ini menunjukkan kriteria baik (3) buku ada dan diisi lengkap oleh sekertaris kelompok.

9) Buku produktivitas dan hasil produksi, sangat dibutuhkan dalam kegiatan kelompok, yang didalamnya berisi catatan tentang hasil panen yang diterima. Banyak kendala-kendala yang dihadapi kelompok wanita tani lestari 2 yaitu saat menghitung hasil produksi yang diterima dikarenakan pengetahuan yang kurang, maupun pengalaman. Tidak menjadi masalah untuk seorang sekertaris kelompok karena demi menambah pengetahuan ia mengkonfirmasi penyuluh untuk membantu dalam perhitungan produktivitas. Sehingga buku produktivitas dan hasil produksi ini berjalan dengan baik (3) buku ada dan diisi lengkap oleh sekertaris kelompok wanita tani Lestari 2.

10) Buku luas lahan garapan, buku yang mencatat jumlah seluruh lahan yang menjadi tempat penanaman yang menjadi bagian dari kelompok tani. Luas lahan garapan kelompok tani ada yang dimiliki kelompok bersama dan ada juga yang pribadi setiap anggota, untuk luas lahan yang pribadi tidak menjadi masalah karena itu juga dipakai untuk keseluruhan anggota kelompok tani dan tiap hasil panen dibagi kepada anggota kelompok dan untuk penjualan tergantung dari anggota kelompok sendiri. Dari hasil penelitian buku luas lahan garapan baik (3) ada dan diisi lengkap oleh pengurus.

\section{Administrasi Keuangan Kelompok Tani Desa Lenganeng Kecamatan Tabukan Utara}

Administrasi keuangan kelompok tani Lestari 2 Desa Lenganeng dikatakan sangat baik dalam pembuatan kelengkapan buku administrasi keuangan kelompok. Pengurus kelompok tani sangat aktif dalam kegiatan kelompok untuk mengembangkan kelompok tani, tiap tahun kelompok tani Lestari 2 mengadakan proposal untuk melengkapi kebutuhan kelompok dan kelompok tani Lestari 2 selalu mendapat bantuan sosial (Bansos) dari pemerintah yang ada di Kabupaten Kepulauan Sangihe. Tabel 7 menunjukkan administrasi keuangan kelompok tani Lestari 2 Desa Lenganeng Kecamatan Tabukan Utara Kabupaten Kepulauan Sangihe. 
Tabel 4. Jumlah Responden Menurut Tingkat Pendidikan

\begin{tabular}{cccccc}
\hline No & Tingkat & \multicolumn{2}{c}{ Jumlah Responden } & \multicolumn{2}{c}{ Presentase (\%) } \\
\cline { 2 - 6 } & Pendidikan & Lestari 2 & Sengkanaung & Lestari 2 & Sengkanaung \\
\hline 1 & SD & - & 2 & 66,67 & \\
2 & SMP & - & 1 & 33,33 & \\
3 & SLTA & 3 & - & & 100 \\
\hline & Jumlah & 3 & 3 & 100 & 100 \\
\hline
\end{tabular}

Sumber : Diolah dari data primer 2016

Tabel 5. Jumlah Responden Menurut Pengalaman Berusahatani (Tahun)

\begin{tabular}{cccc}
\hline No & $\begin{array}{c}\text { Pengalaman Berusahatani } \\
\text { (Tahun) }\end{array}$ & Jumlah responden & Persentase (\%) \\
\hline 1 & 1 & - & - \\
2 & 2 & - & - \\
3 & 3 & 1 & 16,67 \\
4 & 4 & - & - \\
5 & 5 & - & - \\
6 & 6 & - & 33,33 \\
7 & 7 & 2 & 50,00 \\
8 & 8 & 3 & $\mathbf{1 0 0}$ \\
\hline
\end{tabular}

\section{Sumber : Diolah dari data primer 2016}

1) Buku kas, adalah buku yang digunakan untuk mencatat penerimaan dan pengeluaran keuangan. Buku kas sangat penting bagi suatu organisasi kelompok karena buku kas menjadi salah satu hal yang sangat penting bagi organisasi kelompok. Dari hasil penelitian yang dilakukan buku kas dikategorikan kurang baik (2) buku ada tetapi tidak diisi dengan lengkap oleh kelompok tani Lestari 2, disebabkan karena kelalaian.

2) Buku iuran anggota, merupakan catatan pemasukan kas kelompok yang berasal dari iuran wajib, iuran sukarela tiap anggota kelompok. Dari hasil penelitian buku iuran anggota dikatakan sangat baik dengan bobot (3) buku ada dan diisi dengan lengkap oleh bendahara kelompok tani Lestari, karena setiap pertemuan dalam satu bulan anggota kelompok tani mengadakan iuran deng-

gan jumlah Rp.5.000 - Rp.10.000.

3) Buku tabungan anggota (Arisan), adalah buku yang digunakan untuk mencatat tabungan angggota dan suatu tempat penyimpanan. Buku tabungan anggota yang ada di kelompok tani lestari berupa arisan
4) kelompok sehinga dikategorikan baik (3) buku ada dan diisi lengkap dua kali dalam sebulan sesuai dengan kemampuan anggota kelompok tani biasanya Rp.50.000 Rp.300.000.

5) Buku inventaris, merupakan buku yang mencatat dan menyusun barang - barang yang ada dalam kelompok tani. Buku inventaris dikatakan baik (3) buku ada dan diisi lengkap oleh pengurus inti.

6) Buku penjualan, sangat penting untuk menunjang kemajuan kelompok tani, buku penjualan mencatat segala hasil panen dan hasil olahan kelompok usaha tani yang dijual kepada konsumen. Dari hasil penelitian dikategorikan baik (3) buka ada dan diisi lengkap oleh bendahara kelompok tani Lestari 2 Desa Lenganeng.

7) Buku pembelian, buku yang mencatat barang - barang yang dibeli dan dibutuhkan untuk menunjang kegiatan yang dilakukan kelompok tani Lestari 2. Hasil penelitian ini dikatakan baik (3) buku ada dan isi lengkap oleh pengurus kelompok tani.

8) Buku kepemilikan sarana / prasarana, buku yang mencatat semua peralatan dan perlengkapan yang ada di dalam kelompok tani. Dengan hasil penelitian dikakatan baik buku ada dan diisi lengkap oleh pengurus inti dalam kelompok tani. 


\section{Administrasi Kegiatan Kelompok Tani Sengkanaung Desa Talolang Kecamatan Tabukan Utara}

Administrasi kegiatan kelompok tani Sengkanaung Desa Talolang Kecamatan Tabukan Utara dikatakan tidak baik dalam kelengkapan dan pembukuan administrasi kegiatan. Karena kurangnya keaktifan dalam kelompok tani Sengkanaung, tidak ada kerjasama yang baik pengurus dengan anggota, penyuluh dengan semua anggota kelompok tani, dan kurangnya pengetahuan kelompok tani tentang kelengkapan buku administrasi kegiatan. Tabel 8 menunjukkan administrasi kegiatan kelompok tani Sengkanaung Desa Talolang Kecamatan Tabukan Utara Kabupaten Kepulauan Sangihe.

Kelompok tani Sengkanaung Desa Talolang merupakan desa binaan Badan Penyuluhan Pertanian Perikanan dan Kehutanan (BP3K) Talolang yang ada di Kecamatan Tabukan Utara. Kelompok tani berdiri tahun 2009 dengan jumlah anggota 15 orang dengan pendidikan rata-rata tamatan SD (Sekolah Dasar) dan SMP (Sekolah Menengah Pertama), jarak yang ditempuh untuk sampai ke kelompok tani sangat dekat dengan waktu 10 menit dari kantor BP3K.

Administrasi kegiatan kelompok tani dilihat dari penelitian ini kurang adanya kerjasama antara pengurus dan anggota, administrasi yang ada di kelompok tani Sengkanaung rata-rata dikatakan tidak baik dalam melengkapi pembukuan karena tidak adanya kerjasama antar anggota, kurangnya sosialisasi untuk anggota kelompok dari penyuluh, kurangnya rapat anggota, kurangnya pengalaman sehingga hampir semua anggota tidak mengetahui cara melengkapi buku administrasi keuangan, dan juga sekertaris bendahara dan anggota yang lain tidak terlalu aktif dalam kegiatan, yang aktif dan mengelola administrasi di kelompok tani yaitu ketua dengan umur 72 tahun dikatakan sudah terlalu tua dalam mengelola, tetapi dengan semangat dan tanggung jawab yang diemban, kesehatan dan umur tidak mempengaruhi aktivitasnya dalam kelompok tani agar supaya kelompok tani bisa berkembang.

Ada beberapa buku administrasi kegiatan yang kriteria dikatakan kurang baik (2) ada dan diisi lengkap dan baik (3) ada dan diisi lengkap dan juga tidak baik (1) oleh pengurus kelompok tani, yaitu :

1) Buku induk anggota, ketua sangat aktif mengelola buku induk anggota dari tahun berdiri sampai dengan sekarang kelengkapan catatan buku induk anggota sangat penting ketika ada yang mengundurkan diri menjadi anggota kelompok dan anggota baru yang bergabung dengan kelompok tani, nama dan identitas dicatat dalam pembukuan sehingga dikatakan baik (3) buku ada dan diisi lengkap oleh ketua kelompok tani Sengkanaung.

2) Buku kegiatan kelompok, dilihat dari penelitian ini buku kegiatan kelompok dikatakan tidak baik (1) buku tidak ada dalam kelengkapan admnistrasi kelompok tani. Karena setiap kegiatan yang dilakuan kelompok seperti kegiatan penanaman, pertemuan, tidak dicatat dalam pembukuan.

3) Buku tamu, dilihat dari hasil penelitian buku tamu kelompok tani Sengkanaung dikatakan tidak baik (1) kelengkapan administrasi kegiatan buku tamu tidak ada, setiap tamu yang datang berkunjung tidak di catat dalam pembukuan.

4) Buku notulen rapat, dalam kelompok tani Sengkanaung pada saat penelitian tidak ada buku notulen rapat sehingga dikategorikan pada kriteria tidak baik dengan skor (1). Tidak adanya buku notulen rapat disebabkan oleh kerja sama dalam kepengurusan inti tidak baik, yaitu sekertaris yang biasa memegang atau mengurus administrasi sudah kurang aktif dalam kelompok.

5) Buku agenda surat masuk dan surat keluar, sesuai dengan hasil penelitian pada kelompok tani Sengkanaung, tidak memiliki buku agenda surat masuk dan surat keluar sehingga dikategorikan pada kriteria tidak baik (1). Penyebab tidak adanya buku agenda surat masuk dan surat keluar karena setiap adanya pemberitahuan baik dari Dinas Pertanian atau dari pihak manapun hanya melalui SMS dan Telepon kepada pengurus kelompok tani Sengkanaung dalam hal ini ketua.

6) Buku ekspedisi, pada kelompok tani Sengkanaung pada hasil penelitian yang dilakukan tidak memiliki buku ekspedisi sehingga dikategorikan pada kriteria tidak baik (1). Penyebab tidak adanya buku ekspedisi yang membuat kelengkapan 
admisitrasi yaitu berhubungan dengan tidak adanya surat masuk dan keluar.

7) Buku pengurus, dari hasil penelitian pada kelompok tani Sengkanaung tidak memiliki buku pengurus dan di kategorikan tidak baik (1). Hal ini disebabkan oleh sumber daya manusia yang kurang, karena latar belakang anggota dalam Kelompok Tani Sengkanaung rata-rata SD.

8) Buku daftar hadir, kelompok tani sengkanaung memiliki buku daftar hadir tetapi tidak diisi dengan lengkap dan dikategorikan kurang baik (2). Sesuai hasil penelitian yang dilakukan penyebab terjadinya tidak lengkapnya buku daftar hadir yaitu tidak semua kegiatan memiliki daftar hadir dan tidak ada dokumen daftar hadir dari tahun berdiri. Buku daftar hadir kelompok tani Sengkanaung hanya dalam kertas hvs tidak dalam bentuk pembukuan.

9) Buku produktivitas dan hasil produksi, dari penelitian yang dilakukan dalam Kelompok Tani Sengkanaung, tidak terdapat buku produktivitas dan hasil produksi sehingga dikategorikan tidak baik (1). Hal ini disebabkan kurangnya sosialisasi yang dilakukan mengenai kelengkapan administrasi kelompok tani.

10) Buku luas lahan garapan, dari hasil penelitian yang dilakukan di kelompok tani Sengkanaung memiliki buku luas lahan garapan tetapi tidak diisi dengan lengkap dan dikategorikan kurang baik (2). Buku luas lahan tidak diisi lengkap karena hanya lahan yang menjadi percontohan saja yang dicatat dalam pembukuan.

Tabel 6. Administrasi Kegiatan Kelompok Tani Lestari 2 Desa Lenganeng

\begin{tabular}{clcc}
\hline No & \multicolumn{1}{c}{ Administrasi Kegiatan } & Alternative Skor & Alternativ Jawaban \\
\hline 1 & Buku Induk Anggota & 3 & Baik \\
2 & Buku Kegiatan Kelompok & 3 & Baik \\
3 & Buku Tamu & 3 & Baik \\
4 & Buku Notulen Rapat & 3 & Baik \\
5 & Buku Agenda Surat Masuk dan Surat & 1 & Tidak Baik \\
& keluar & 1 & Tidak Baik \\
6 & Buku Ekspedisi & 3 & Baik \\
7 & Buku Pengurus & 3 & Baik \\
8 & Buku Daftar Hadir & 3 & Baik \\
9 & Buku Produktifitas dan Hasil Produksi & 3 & Baik \\
10 & Buku Luas Lahan Garapan & $\mathbf{2 6}$ & \\
\hline & Jumlah & & \\
\hline Sumber : Diolah dari data primer 2106 &
\end{tabular}

Tabel 7. Administrasi Keuangan Kelompok Tani Lestari 2 Desa Lenganeng

\begin{tabular}{clcc} 
No & \multicolumn{1}{c}{ Administrasi Keuangan } & Alternativ Skor & Alternativ Jawaban \\
\hline 1 & Buku Kas & 2 & Kurang Baik \\
2 & Buku Iuran Anggota & 3 & Baik \\
3 & Buku Tabungan Anggota (arisan) & 3 & Baik \\
4 & Buku Inventaris & 3 & Baik \\
5 & Buku Penjualan & 3 & Baik \\
6 & Buku Pembelian & 3 & Baik \\
7 & Buku Kepemilikan Sarana / Prasarana & 3 & Baik \\
\hline & Jumlah & $\mathbf{2 0}$ &
\end{tabular}

Sumber : Diolah dari data primer 2016

\section{Administrasi Keuangan Kelompok Tani Sengkanaung Desa Talolang}

Administrasi keuangan kelompok tani Sengkanaung Desa Talolang terlaksana 
dengan baik buku tidak ada dengan kriteria (1) dan ada beberapa buku dikatakan baik (2) buku ada tetapi tidak diisi dengan lengkap oleh pengurus. Kelompok tani Sengkanaung tiap tahun membuat proposal untuk membantu kegiatan yang dilakukan dalam kelompok dan mendapat bantuan sosial dari pemerintah Kabupaten Kepulauan Sangihe berupa pupuk dan keperluan yang lainnya untuk mengembangkan usaha tani kelompok Sengkanaung. Administrasi keuangan kelompok tani Sengkanaung Desa Talolang Kecamatan Tabukan Utara dapat dilihat pada Tabel 9.

1. Pada Buku kas, dari hasil penelitian yang dilakukan di kelompok tani Sengkanaung Desa Talolang Kecamatan Tabukan Utara, dikategorikan kurang baik (2) buku ada tetapi tidak diisi dengan lengkap oleh bendahara kelompok, karena kurang kehadiran, kurang kerjasama sehingga buka kas tidak tercatat dengan baik dan rinci.

2. Buku iuran anggota, dengan hasil penelitian dikatakan tidak baik (1) karena tidak ada kegiatan pengumpulan iuran dalam kelompok untuk memenuhi kebutuhan kelompok tani. Buku tabungan anggota, hasil penelitian untuk kelengkapan buku keuangan yang ada di kelompok tani Seng kanaung Desa Talolang, buku tabungan anggota dikategorikan tidak baik (1) karena kelompok tani Sengkanaung anggotanya sudah tidak terlalu aktif dalam kelompok.

3. Buku inventaris, sangat penting bagi suatu organisasi karena buku iventaris mencatat barang-barang yang dimiliki kelompok tani baik itu milik sendiri maupun milik pemerintah, namun dari hasil penelitian menunjukkan bahwa buku inventaris kelompok tani sengkanaung dikategorikan tidak baik (1) karena tidak ada pembukuan yang dimilik kelompok tani.

4. Buku penjualan, dari hasil penelitian yang dilakukan pada kelompok tani Sengkanaung Desa Talolang dikategorikan tidak baik (1) karena tidak ada catatan dan buku penjualan dari usaha yang dilakukan oleh kelompok tani.

5. Buku pembelian, buku pembelian dikatakan baik (2), karena buku ada tetapi tidak diisi lengkap oleh pengurus yang bertanggung jawab dalam buku pembelian, dan disertai dengan nota pembelian.

6. Buku kepemilikan sarana prasarana, dari hasil penelitian ini buku kepemilikan sarana prasarana dikategorikan tidak baik (1) karena tidak ada pembukuan dan catatan yang di miliki kelompok tani Sengkanaung Desa Talolang Kecamatan Tabukan Utara.

Tabel 8. Administrasi Kegiatan Kelompok Tani Sengkanaung Desa Talolang

\begin{tabular}{clcc}
\hline No & \multicolumn{1}{c}{ Administrasi Kegiatan } & $\begin{array}{c}\text { Alternative } \\
\text { Skor }\end{array}$ & $\begin{array}{c}\text { Alternatif } \\
\text { Jawaban }\end{array}$ \\
\hline 1 & Buku Induk Anggota & 3 & Baik \\
2 & Buku Kegiatan Kelompok & 1 & Tidak Baik \\
3 & Buku Tamu & 1 & Tidak Baik \\
4 & Buku Notulen Rapat & 1 & Tidak Baik \\
5 & Buku Agenda Surat Masuk dan Surat keluar & 1 & Tidak Baik \\
6 & Buku Ekspedisi & 1 & Tidak Baik \\
7 & Buku Pengurus & 1 & Tidak Baik \\
8 & Buku Daftar Hadir & 2 & Kurang Baik \\
9 & Buku Produktifitas dan Hasil Produksi & 1 & Tidak baik \\
10 & Buku Luas Lahan Garapan & 2 & Kurang Baik \\
\hline & Jumlah & $\mathbf{1 4}$ & \\
\hline
\end{tabular}

Sumber : Diolah dari data primer 2016 
Tabel 9. Administrasi Keuangan Kelompok Tani Sengkanaung Desa Talolang Kecamatan Tabukan Utara

\begin{tabular}{clcc}
\hline No & \multicolumn{1}{c}{ Administrasi Keuangan } & Alternativ Skor & Alternativ Jawaban \\
\hline 1 & Buku Kas & 2 & Kurang Baik \\
2 & Buku Iuran Anggota & 1 & Tidak Baik \\
3 & Buku Tabungan Anggota (arisan) & 1 & Tidak Baik \\
4 & Buku Inventaris & 1 & Tidak Baik \\
5 & Buku Penjualan & 1 & Tidak Baik \\
6 & Buku Pembelian & 2 & Tidak Baik \\
$\mathbf{7}$ & Buku Kepemilikan Sarana / & 1 & Tidak Baik \\
& Prasarana & & \\
\hline & Jumlah & $\mathbf{9}$ & \\
\hline
\end{tabular}

Sumber : Diolah dari data primer 2016

\section{KESIMPULAN DAN SARAN}

\section{Kesimpulan}

Dari hasil penelitian pada dua kelompok tani yang mewakili semua kelompok tani yang ada di Kecamatan Tabukan Utara, menunjukkan bahwa administrasi penyuluhan pertanian pada kelompok tani di Kecamatan Tabukan Utara Kabupaten Kepulauan Sangihe khususnya administrasi kegiatan dan administrasi keuangan pada kelompok tani Lestari 2 Desa Lenganeng semua kelengkapan buku administrasi di kategorikan baik (3) karena keaktifan, kebersamaan pengurus dengan anggota, ada anggota dengan penyuluh kelompok tani dalam melakukan semua kegiatan.

Administrasi kegiatan dan administrasi keuangan yang ada di kelompok tani Sengkanaung Talolang tidak berjalan dengan baik dan dikategorikan tidak baik (1) karena tidak ada kerjasama antara anggota kelompok tani, begitu juga anggota dengan penyuluh, serta pengetahuan yang kurang, dan kurangnya penyuluhan bagi kelompok tani tentang kelengkapan administrasi kegiatan dan administrasi keuangan. Kelompok tani yang dekat dengan kantor BP3K dan kelompok tani yang jauh dari BP3K tidak mempengaruhi kelengkapan administrasi kegiatan dan keuangan yang ada di Kecamatan Tabukan Utara Kabupaten Kepulauan Sangihe karena dari hasil penelitian ini kelompok tani yang jauh lebih aktif dalam kegiatan kelompok dari pada kelompok tani yang dekat dengan kantor BP3K.

\section{Saran}

Berdasarkan dari hasil penelitian maka disarankan kepada :

a. BP3K (Balai penyuluhan pertanian perikanan dan kehutanan) sebaiknya penyuluh harus lebih meperhatikan kelompok-kelompok tani yang ada di Kecamatan Tabukan Utara, dan sebaiknya memberikan penyuluhan tentang admnistrasi kepada kelompok tani agar bisa menambah wawasan serta pengetahuan anggota kelompok tani.

b. Kelompok tani sebaiknya lebih memperhatikan dan melengkapi pembukuan administrasi kegiatan dan administrasi keuangan. Ketika ada pemeriksaan dari BP3K dan lembagalembaga lain yang bekerja sama dengan kelompok tani, sehingga tidak terjadi masalah terlebih kusus administrasi keuangan.

\section{DAFTAR PUSTAKA}

Nopriadi, 2013.Ahli Fungsi Lahan Pertanian Menjadi Tempat Pemukiman Di Kelurahan Jati Hilir Kecamatan Pariman Tengah Kota, Jurnal Pendidikan Geografi, Vol 2, No 1.

Ode,H., 2014. Pengembangan Organisasi pada Waroeng Steak and Shake Berbasis Spiritual. Thesis.

Ridwan, 2012. Pengantar Statistika Sosial. Bandung. 